\title{
Emerging functions of pannexin 1 in the eye
}

\section{Sarah Kurtenbach ${ }^{1}$, Stefan Kurtenbach ${ }^{1}$ and Georg Zoidl ${ }^{1,2 *}$}

' Department of Psychology, Faculty of Health, York University, Toronto, ON, Canada

${ }^{2}$ Department of Biology, Faculty of Science, York University, Toronto, ON, Canada

\section{Edited by:}

Juan Andrés Orellana, Pontificia

Universidad Católica de Chile, Chile

\section{Reviewed by:}

Sheriar Hormuzdi, University of

Dundee, UK

Brant Isakson, University of Virginia, USA

\section{*Correspondence:}

Georg Zoidl, Department of Biology, Faculty of Science, York University, Life Science Building 323A, 4700

Keele Street, Toronto,

ON M3J 1P3, Canada

e-mail: gzoid@@yorku.ca
Pannexin 1 (Panx1) is a high-conductance, voltage-gated channel protein found in vertebrates. Panx 1 is widely expressed in many organs and tissues, including sensory systems. In the eye, Panx 1 is expressed in major divisions including the retina, lens and cornea. Panx 1 is found in different neuronal and non-neuronal cell types. The channel is mechanosensitive and responds to changes in extracellular ATP, intracellular calcium, $\mathrm{pH}$, or ROS/nitric oxide. Since Panx1 channels operate at the crossroad of major signaling pathways, physiological functions in important autocrine and paracrine feedback signaling mechanisms were hypothesized. This review starts with describing in depth the initial Panx1 expression and localization studies fostering functional studies that uncovered distinct roles in processing visual information in subsets of neurons in the rodent and fish retina. Panx 1 is expressed along the entire anatomical axis from optical nerve to retina and cornea in glia, epithelial and endothelial cells as well as in neurons. The expression and diverse localizations throughout the eye points towards versatile functions of Panx 1 in neuronal and non-neuronal cells, implicating Panx 1 in the crosstalk between immune and neural cells, pressure related pathological conditions like glaucoma, wound repair or neuronal cell death caused by ischemia. Summarizing the literature on Panx 1 in the eye highlights the diversity of emerging Panx 1 channel functions in health and disease.

Keywords: pannexin 1 (Panx1), eye, retina, lens, cornea, purinergic receptor signaling, ATP, feedback mechanism

\section{INTRODUCTION}

In the year 2000, pannexin (Panx) genes (Panx, Latin: pan = complete, everywhere and nexus $=$ junction) were described as putative gap junction proteins based on a distant sequence homology to innexins, the gap junction proteins of invertebrates. In higher vertebrates, the Panx gene family consists of the three glycosylated integral membrane proteins Panx1, Panx2 and Panx3 (Panchin et al., 2000; Bruzzone et al., 2003; Baranova et al., 2004). Although, initial studies suggested that under certain conditions pannexins might be able to form gap junction channels in vitro (Bruzzone et al., 2003, 2005; Vanden Abeele et al., 2006; Lai et al., 2007), experimental evidence suggests that pannexins function as unopposed single membrane channels in vivo (Sosinsky et al., 2011).

Today, Panx 1 is the best-characterized family member. Panx1 is almost ubiquitously expressed and found in many organs as well as in several cell types of the blood and immune system (Dvoriantchikova et al., 2006a,b; Locovei et al., 2006a; Penuela et al., 2007; Schenk et al., 2008; Seminario-Vidal et al., 2009, 2011; Celetti et al., 2010; Sridharan et al., 2010; Woehrle et al., 2010; Kienitz et al., 2011; Hanner et al., 2012). In the CNS, Panx1 shows a widespread distribution and largely co-localizes with Panx2 (Bruzzone et al., 2003; Ray et al., 2005; Vogt et al., 2005; Dvoriantchikova et al., 2006a,b; Ray et al., 2006; Zappalà et al., 2006, 2007), where the expression is mainly neuronal (Ray et al., 2005, 2006; Zoidl et al., 2007). Evidence for glial expression was found in cultured astrocytes and oligodendrocytes (Boassa et al.,
2007; Huang et al., 2007a; Iglesias et al., 2009a; Suadicani et al., 2012). Further, Panx1 expression has been described in major sensory systems including the eye, inner ear, taste buds, and the olfactory epithelium (Bruzzone et al., 2003; Huang et al., 2007b; Romanov et al., 2007; Tang et al., 2008; Dando and Roper, 2009; Wang et al., 2009; Zhang et al., 2012). Panx2 is expressed in the eye, thyroid, kidney and liver, with highest expression levels in the brain and spinal cord (Bruzzone et al., 2003; Baranova et al., 2004; Vogt et al., 2005; Dvoriantchikova et al., 2006a,b; Ray et al., 2006). In humans, Panx2 expression is presumably brain specific. Panx 3 is mainly expressed in the skin and cartilage, but can also be found in the heart ventricle, cochlea as well as in lung, kidney, thymus, liver and spleen and possibly astrocytes (Bruzzone et al., 2003; Penuela et al., 2007; Wang et al., 2009; Celetti et al., 2010).

Panx1 forms large-conductance channels, activated by changes in membrane potential, ATP, intracellular calcium, stretch, $\mathrm{pH}$, elevated extracellular potassium, and following purinergic receptor activation (Bao et al., 2004a; Locovei et al., 2006a,b; Qiu and Dahl, 2009; Kawamura et al., 2010; Kienitz et al., 2011; Qiu et al., 2011; Kurtenbach et al., 2013). Channel opening and closing are subject to a plethora of molecular mechanisms including protein interactions, and post-translational modifications like glycosylation and S-nitrosylation (Johnstone et al., 2012; Lohman et al., 2012b; D'hondt et al., 2013; Penuela et al., 2014b; Retamal, 2014). Since Panx1 channels operate at the crossroad of major signaling pathways, foremost those involving intracellular calcium, extracellular ATP or ROS/nitric oxide, physiological functions in 
important autocrine and paracrine feedback signaling mechanisms were hypothesized (Kawamura et al., 2010; Kronlage et al., 2010; Lohman et al., 2012a; Bao et al., 2013). Further interest in Panxl derives from independent lines of evidence supporting a critical role of Panx1 in pathological conditions. There, opening of Panx1 channels, frequently together with activation of purinergic receptors by extracellular ATP, has been implicated in diverse conditions including, but not limited to, ischemia (Madry et al., 2010; Monaco and Friedlander, 2012), trauma (Minkiewicz et al., 2013), seizures (Zappalà et al., 2006; Thompson et al., 2008; Mylvaganam et al., 2010; Kim and Kang, 2011; Santiago et al., 2011), HIV infection (Séror et al., 2011; Orellana et al., 2013), inflammation (Kanneganti et al., 2007; Schenk et al., 2008; de Rivero Vaccari et al., 2009; Lamkanfi et al., 2009; Schalper et al., 2009; Silverman et al., 2009), migraine (Karatas et al., 2013), and tumor cell growth (Lai et al., 2007; Penuela et al., 2012).

Important developments in Panx research and emerging roles in health and disease have been covered recently in excellent reviews (MacVicar and Thompson, 2010; Dahl and Keane, 2012; Bond and Naus, 2014; Penuela et al., 2014b). This review will address emerging roles of Panx 1 in the eye. The anatomical axis of the eye is used to guide the reader through each chapter. Original studies demonstrating the expression and localization of Panx1 in neuronal and non-neuronal cell types throughout the eye are summarized (overview see Table 1). Furthermore, known functions are described, otherwise emerging roles of Panx1 in physiological and pathological conditions are highlighted and challenges outlined. In concluding remarks, functional diversity is discussed as the overarching theme. Readers interested in the roles of connexins in the eye can consult recently published reviews (Volgyi et al., 2013; Vroman et al., 2013; Berthoud et al., 2014; Beyer and Berthoud, 2014).

\section{PANX1 IN THE RODENT RETINA: PROCESSING VISUAL INFORMATION}

After the initial discovery of Panx expression in the eye (Bruzzone et al., 2003), refined characterizations of the rodent retina using in situ hybridization analysis and RT-PCR analysis of tissue captured by laser microdissection revealed Panx1 and Panx 2 expression in the ganglion cell layer (GCL), inner nuclear layer (INL), the outer nuclear layer (ONL) and to a lesser extent in the inner plexiform layer (IPL; Ray et al., 2005; Dvoriantchikova et al., 2006a). In general, two Panx1 protein isoforms (43 kDa, $58 \mathrm{kDa})$ were found in the retina and brain, of which the $58 \mathrm{kDa}$ variant is post-translationally modified (Kranz et al., 2013). RT-PCR and immunohistochemistry (IHC) revealed mRNA and protein expression regulation during development with a transient expression peak around birth, declining with age (Ray et al., 2005; Dvoriantchikova et al., 2006a). In neonatal and P20 animals, Panx1 labeling was prominent in retinal ganglion cells (RGC), amacrine cells and horizontal cells (HC) in the outer plexiform layer (OPL), whereas in adult animals the labeling mainly occurred in RGCs. Panx1 proteins were localized at the cell surface and neuronal processes.

More detailed analyses of mice retinae revealed Panx1 proteins in a puncta-like pattern on the soma and dendritic branches, sparsely along the axon, and more intensively at the axon terminal of type 3a OFF bipolar cells (CB3a cells) and on non-invaginating cellular processes at the base of rod spherules, resembling the flat contact between rods and cone bipolar cells. The authors also confirmed the expression of Panxl in HC using single cell RTPCR, IHC and ultrastructural analysis and found Panx1 localized at the tips of $\mathrm{HC}$ dendrites invaginating in rod spherules. It is worth noting that only one HC type is present in the murine retina receiving cone input at the dendrites and rod input at the axon terminals (Peichl and Gonzalez-Soriano, 1993) in contrast to the zebrafish retina possessing two types of $\mathrm{HC}$ that either make contacts to rods or cones, with the zebrafish drPanxla (see below) found only at the HC cone synaptic complexes (Prochnow et al., 2009). In mice, the P2X7 receptor (P2X7-R), like Panx1, is localized at the tip of HC dendrites (Puthussery et al., 2006), suggesting that P2X7-R and Panx1 functions could be linked and involve the local release of ATP.

Physiological function(s) of Panxl in the processing of visual information were investigated using $\mathrm{Panx}^{-/-}$mice, using in vivo and in vitro electroretinography (ERG). Kranz et al. (2013) demonstrated that under scotopic, but not photopic light conditions, the a- and b-wave amplitude of in vivo ERGs was increased in knockout animals at high light intensity. In vitro studies confirmed this result, and it was concluded that the ablation of Panx1 interferes with the activity of the dark-adapted retina without altering the temporal properties of signal transmission within the retina, but does not affect the cone pathway under light conditions. The authors proposed that Panx1 closes under conditions of prolonged light adaptation as previously observed for retinal gap junctions (Bloomfield et al., 1995; Xin and Bloomfield, 1999). In scotopic light conditions, the changes to the b-wave were explained by the Panx1 channels on the CB3a cells providing a competing current to the light-evoked current of the ON bipolar cells. This might lead to a Panx1-mediated reduction of radial current flow, resulting in an enhanced b-wave in the Panx $1^{-/-}$mice. The a-wave reflects the reduction of the dark current during light stimulation and is made up of an extracellular radial current from the photoreceptor inner segment towards the outer segments (Penn and Hagins, 1969) and from currents arising from the photoreceptor synapse (Hagins et al., 1970). In this context, Panxl channels on HC dendrites may take part in negative feedback mechanisms leading to a decreased current flow at the photoreceptor synapse, causing an enlarged a-wave if Panx1 channels are not present. A mechanism addressing this feedback has been previously put forward for connexin hemichannels in the fish and turtle retina and new insight will follow below (Kamermans et al., 2001; Pottek et al., 2003; Kamermans and Fahrenfort, 2004).

\section{PANX1 ORTHOLOGS IN THE FISH RETINA: FEEDBACK REGULATION IN THE OUTER RETINA}

The retina of zebrafish shares many properties with those of higher vertebrates, but color vision is more similar to the human trichromatic vision when compared to the murine dichromatic vision (Goldsmith and Harris, 2003; Conway, 2007). Series of genome duplication events in teleost evolution caused partial gene duplications approximately 320-350 million years ago (Jaillon et al., 2004; Postlethwait, 2007; Ravi and Venkatesh, 2008). As a 
Table 1 | Summary of known and emerging functions of pannexins in the eye.

\begin{tabular}{|c|c|c|c|c|c|c|}
\hline Organism & Protein & Localization & Cell type & Localization & $\begin{array}{l}\text { Interaction/ } \\
\text { Pathway }\end{array}$ & Function \\
\hline \multirow[t]{13}{*}{ mouse, rat } & Panx1 & $\begin{array}{l}\text { retina: GCL, } \\
\text { IPL, INL, ONL, } \\
\text { OPL }\end{array}$ & $\mathrm{RGC}$ & neuronal processes & n.d. & $\begin{array}{l}\text { neuroprotection, ischemia } \\
\text { induced cell death } \\
\text { (Dvoriantchikova et al., 2012) }\end{array}$ \\
\hline & & & & & $\begin{array}{l}\text { P2X7-R, purinergic } \\
\text { signaling pathway }\end{array}$ & $\begin{array}{l}\text { activation of P2X7-R by } \\
\text { hypotonicity-incuded ATP } \\
\text { release, glaucoma * }\end{array}$ \\
\hline & & & $\mathrm{HC}$ & $\begin{array}{l}\text { dendrites, } \\
\text { invaginating rod } \\
\text { spherules }\end{array}$ & n.d. & n.d. \\
\hline & & & CB3a bipolar cells & $\begin{array}{l}\text { soma, dendritic } \\
\text { branches, axons }\end{array}$ & $\begin{array}{l}\text { P2X7-R, purinergic } \\
\text { signaling pathway }\end{array}$ & $\begin{array}{l}\text { ATP release, photoreceptor- } \\
\text { HC feedback regulation, } \\
\text { neuronal processing (Kranz } \\
\text { etal., 2013) }\end{array}$ \\
\hline & & & amacrine cells & n.d. & n.d. & n.d. \\
\hline & & & microglia & n.d. & $\begin{array}{l}\text { AMPA/kainate } \\
\text { receptor }\end{array}$ & ATP release \\
\hline & & lens & epithelial cells & $\begin{array}{l}\text { predominantlyin } \\
\text { cytoplasm }\end{array}$ & n.d. & n.d. \\
\hline & & & $\begin{array}{l}\text { young elongated } \\
\text { fiber cells }\end{array}$ & $\begin{array}{l}\text { predominantlyin } \\
\text { cytoplasm }\end{array}$ & n.d. & n.d. \\
\hline & & & mature fiber cells & plasma membrane & n.d. & n.d. \\
\hline & & $\begin{array}{l}\text { tunica } \\
\text { vasculosa } \\
\text { lentis }\end{array}$ & endothelial cells & n.d. & n.d. & retinopathy of prematurity * \\
\hline & & cornea & epithelial cells & & $\begin{array}{l}\text { P2X7-R, purinergic } \\
\text { signaling pathway }\end{array}$ & wound repair * \\
\hline & Panx2 & retina: all layers & n.d. & n.d. & n.d. & n.d. \\
\hline & & lens & $\begin{array}{l}\text { epithelium and } \\
\text { fiber cells }\end{array}$ & n.d. & n.d. & n.d. \\
\hline \multirow[t]{3}{*}{ zebrafish } & drPanx1a & retina: OPL & $\mathrm{HC}$ & $\begin{array}{l}\text { mainly cone synaptic } \\
\text { complex, soma }\end{array}$ & n.d. & $\begin{array}{l}\text { pH dependent } \\
\text { photoreceptor-HC feedback } \\
\text { mechanism, ATP release, } \\
\text { neuronal processing (Vroman } \\
\text { etal., 2014) }\end{array}$ \\
\hline & $\mathrm{drPanx} 1 \mathrm{~b}$ & $\begin{array}{l}\text { retina: GCL, } \\
\text { INL }\end{array}$ & amacrine cells* & n.d. & n.d. & n.d. \\
\hline & drPanx2 & Retina & n.d. & n.d. & n.d. & n.d. \\
\hline porcine & Panx1 & lens & $\begin{array}{l}\text { cuboidal epithelial } \\
\text { cells }\end{array}$ & n.d. & $\begin{array}{l}\mathrm{Na}^{+} / \mathrm{K}^{+}-\text {ATPase, } \\
\text { P2Y-R, TRPV4 }\end{array}$ & $\begin{array}{l}\text { pressure regulation } \\
\text { 1. Hyposmotic stress } \\
\text { mediated ATP release } \\
\text { 2. Hyposmotic stress } \\
\text { mediated } \mathrm{Ca}^{2+} \text { influx } \\
\text { activates Panx } 1 \text { mediating }\end{array}$ \\
\hline \multirow[t]{2}{*}{ bovine } & Panx1 & $\begin{array}{l}\text { trabecular } \\
\text { meshwork } \\
\text { cells }\end{array}$ & n.d. & n.d. & P2X7-R, connexins & $\begin{array}{l}\text { pressure-activated ATP } \\
\text { release, glaucoma* }\end{array}$ \\
\hline & & $\begin{array}{l}\text { ciliary epithelial } \\
\text { cells }\end{array}$ & n.d & n.d. & $\begin{array}{l}\text { connexins, P2X7-R } \\
\text { and independent } \\
\text { vesicular ATP } \\
\text { release }\end{array}$ & $\begin{array}{l}\text { hypotonicity-triggered ATP } \\
\text { release }\end{array}$ \\
\hline
\end{tabular}

n.d. indicates category not determined.

* indicates emerging functions or indirect association with disease/disorders. 
consequence, the zebrafish genome encodes for two Panxl genes, drPanxla and drPanx1b (Bond et al., 2012; Kurtenbach et al., 2013), and single drPanx 2 and drPanx 3 genes. In the zebrafish retina, drPanxla, drPanxlb and three differently spliced mRNA transcripts of drPanx2 are expressed (Zoidl et al., 2008; Prochnow et al., 2009; Kurtenbach et al., 2013). The retinal expression of drPanxla and drPanxib has been further characterized using IHC. drPanxla was found in a band-like, horseshoe shape pattern in the OPL on HC dendrites, but also on HC somata (Prochnow et al., 2009; Kurtenbach et al., 2013). No labeling could be found on other cell types like ON bipolar cells or interplexiform cells. Ultrastructural analysis revealed the expression of drPanxla on HC dendrites inserted deeply in the cone synaptic complex, where they are located more distal from the cones' glutamate release sites compared to Cx55.5 hemichannels. No expression in rod synaptic terminals was found. IHC located drPanxib in the GCL and in the INL suggestive for a potential localization in amacrine cells (Kurtenbach et al., 2013). Like mammalian Panx1, drPanxla and drPanxlb are glycoproteins, with drPanxlb having three possible $\mathrm{N}$-glycosylation sites and drPanxla one. Fish pannexins, like mammalian Panx channels, form voltage-gated single membrane channels with shared and unique properties, including activation under physiological conditions, modulation by extracellular ATP, intracellular $\mathrm{Ca}^{2+}$ and $\mathrm{pH}$ changes (Kurtenbach et al., 2013).

Exciting novel results highlighted the role of drPanxla in neuronal processing at the first retinal synapse, where HCs inhibit photoreceptors. This interaction generates the center/surround organization of bipolar cell receptive fields and is crucial for contrast enhancement (Burkhardt and Fahey, 1998; Jackman et al., 2011). Two competing hypotheses considered an ephaptic or a proton-mediated mechanism to explain this fundamental process (Kamermans et al., 2001; Kamermans and Fahrenfort, 2004; Fahrenfort et al., 2009; Hirasawa et al., 2012; Klaassen et al., 2012; Vroman et al., 2013). Since zebrafish with a functional knock out of the HC specific Cx55.5 retained 40\% hemichannel conductance, it was tempting to speculate that other connexins or a Panx could account for the residual $40 \%$ conductance (Klaassen et al., 2011; Sun et al., 2012). The Kamermans group was able to answer this long-standing, fundamental question demonstrating that $\mathrm{HC}$ feedback to photoreceptors via an unexpected synthesis of both mechanisms (Vroman et al., 2014). The first one is a very fast connexin driven ephaptic mechanism, which has no synaptic delay making it one of the fastest inhibitory synapses known. The second one is a relatively slow mechanism, depending on ATP released via Panxl channels located on horizontal cell dendrites deeply invaginating the cone synaptic terminal.

The unique finding was that the extracellular ATP hydrolysis to AMP, phosphate groups and protons, formed a buffer with a pKa of 7.2. This inhibited $\mathrm{Ca}^{2+}$-channels in cones, and consequently reduced the cones' glutamate release. Since cone photoreceptors and HCs form a reciprocal synapse with cones transmitting to HCs through an excitatory synapse and HCs feeding back to cones through an inhibitory synapse, the reduction of glutamate release caused hyperpolarization in HCs, a condition that evoked a decrease of Panx1 channels conductance. Decreasing ATP release caused alkalization in the synaptic cleft and consequently increased cone glutamate release. Surprisingly, the hydrolysis of ATP instead of ATP itself mediated the synaptic modulation, revealing a novel form of synaptic modulation. Since Panxl channels and ecto-ATPases are strongly expressed in the nervous system and Panxl function was previously implicated in synaptic plasticity, learning and behavior (Prochnow et al., 2012), the authors hypothesized that this novel form of synaptic modulation might be a wide spread phenomenon.

\section{PANX1 IN RETINAL MICROGLIA: IMPLICATIONS FOR CROSSTALK OF IMMUNE AND NEURAL CELLS}

Panx1-mediated ATP release has been associated with the regulation of the morphology and behavior of "resting" microglia in the retina, the primary resident immune cells in the CNS, because of endogenous, ionotropic glutamatergic neurotransmission (Fontainhas et al., 2011). In their "resting" state, microglia have a ramified morphology with fine, extended processes, which exhibit rapid dynamics to make repeated contacts with neurons, glia and blood vessels (Davalos et al., 2005; Nimmerjahn et al., 2005; Lee et al., 2008). The factors that regulate "resting" microglia and induce their transformation to the "activated" state are not fully understood, but a credible hypothesis is that gradients of "on" and "off" signals activate/repress microglial activation involving extracellular signals like ATP, purinergic receptors, glutamate receptors, chemokines and neurotransmission (Mertsch et al., 2001; Xiang et al., 2006; Liang et al., 2010; Wong et al., 2011; Domercq et al., 2013). Experimental evidence suggesting Panx1 involvement derived from ex vivo retinal mouse explants, pharmacological intervention of retinal neurotransmission and analysis of microglia morphology (Fontainhas et al., 2011). Microglial morphology and dynamic behavior was modulated by retinal neurotransmission. Endogenous ionotropic glutamate through AMPA/kainate receptors maintained and increased dendritic morphology and process motility, whereas ionotropic GABAergic neurotransmission negatively regulated the morphology and motility. Since the application of probenecid decreased the AMPA mediated effects on microglia, the authors concluded that the response to neurotransmitter was mediated indirectly via secondary ATP, released in response to glutamatergic neurotransmission through probenecid-sensitive Panx channels. Interestingly, the effects of fast AMPA/kainate receptors on microglia were larger compared to those of slow NMDA receptors, although NMDA receptor stimulation has been shown triggering Panx1 opening in pyramidal neurons leading to epileptiform seizure activity (Thompson et al., 2008). This mode of constitutive signaling between neural and immune cells of the CNS illustrates the versatility of Panxl channels for distinct physiological processes in the retina and beyond.

\section{PANX1 IN RETINAL GANGLION CELLS: IMPLICATIONS FOR ISCHEMIC DISORDERS OF THE RETINA}

A role of Panx1 channels in the pathology of the retina was investigated using conditional Panx1 $1^{-/}$mice and oxygen-glucose deprivation (OGD) to demonstrate whether Panx1 is part of a pathological cascade leading to ischemia-induced RGC loss (Dvoriantchikova et al., 2012). They found that Panx1 deficiency protects RGCs from death induced by ischemia, most likely by preventing rapid membrane permeation and Panx1 activation as 
part of the activation of neuronal inflammasome. It was concluded that Panxl is activated at a convergence point for several neurotoxic pathways. Further, it was suggested that the Panx1 channel is a potential target for therapeutic intervention in retinal ischemic disorders.

\section{PANX1 IN THE LENS: IMPLICATIONS FOR A ROLE IN HYPOOSMOTIC STRESS}

The vertebrate lens is an avascular tissue with extensive gap junctional and hemichannel coupling supporting growth, differentiation and homeostasis. Using qRT-PCR and in situ hybridization, Dvoriantchikova et al. (2006b) demonstrated Panx1 and Panx2 mRNA expression in the lens epithelium and fiber cells. Relative to Cx50, the most abundant connexin expressed in the mouse lens, Panx1 and Panx2 expression is significantly lower in the epithelium and the fiber cells. Western blot analyses revealed four Panx1 protein isoforms: two major protein bands (43 and $120 \mathrm{kDa}$ ) and two minor bands (58 and $62 \mathrm{kDa}$ ). Using differential centrifugation, the monomeric $43 \mathrm{kDa}$ protein was found in the soluble protein fraction, whereas the $62 \mathrm{kDa}$ variant was present in the microsomal, organelle-enriched fraction, likely associated with the ER and Golgi apparatus. Further detergent extraction with Triton X-100 and methyl- $\beta$-cyclodextrin suggested association of the $58 \mathrm{kDa}$ and $120 \mathrm{kDa}$ isoforms with lipid raft membrane microdomains. The water-insoluble Panx1 62 and $120 \mathrm{kDa}$ isoforms were lens and retina specific, whereas $58 \mathrm{kDa}$ species is found in non-CNS tissues. Expression was age and cell type dependent, with the $120 \mathrm{kDa}$ protein predominantly expressed in mature and young fibers, whereas the $58 \mathrm{kDa}$ species was mainly present in the lens epithelium and the young elongating fibers. IHC analysis revealed that Panx1 proteins were predominantly located in the lens cortex and that expression declined towards the lens nucleus. The subcellular distribution was consistent with the expected live cycle of the Panx1 channel protein. During development, redistribution occurred shifting from a predominant presence in the cytoplasm in epithelial and young elongated fiber cells to a more pronounced localization in the plasma membrane of mature fiber cells.

Potential function(s) of Panx1 in the lens epithelium were investigated using the porcine lens model (Shahidullah et al., 2012). In the lens the cuboidal lens epithelium is located in the anterior portion between the lens capsule and the lens fibers regulating important homeostatic functions and contains a variety of transporters as well as, amongst others, purinergic receptors (Delamere and Tamiya, 2009). Panx1 was correlated with $\mathrm{Na}^{+} / \mathrm{K}^{+}$ATPase activity, an antiporter enzyme with important roles in maintaining resting potential, availing transport, regulating cellular volume, and as a signal transducer/integrator to regulate MAPK pathway, ROS, as well as intracellular calcium. As ions, nutrients, and liquid enter the lens from the aqueous humor, $\mathrm{Na}^{+} / \mathrm{K}^{+}$-ATPases in the lens epithelial cells pump ions out of the lens to maintain appropriate lens osmolarity and volume, with equatorially positioned lens epithelium cells contributing most to this current. The activity of the $\mathrm{Na}^{+} / \mathrm{K}^{+}$-ATPases keeps water and current flowing through the lens from the poles and exiting through the equatorial regions. Similar to mice, $58 \mathrm{kDa}$ and $120 \mathrm{kDa}$ isoforms of Panx1 were detected, further $\mathrm{Cx} 53$ and Cx50, but not Panx2, Panx3 or Cx40. Hypoosmotic, but not a hyperosmotic solution triggered pannexin- and connexinsmediated ATP release increasing $\mathrm{Na}^{+} / \mathrm{K}^{+}$ATPase activity. This activity was pharmacologically reduced by the connexin inhibitor 18a-glycyrrhetinic acid (AGA), and abolished when AGA was combined with the Panxl specific inhibitor probenecid, or when apyrase was added to catalyze the hydrolysis of ATP. Using the exocytosis inhibitor N-ethylmaleimide (NEM), the authors ruled that ATP is released via exocytosis. Using the purinergic P2 receptor antagonist reactive blue- 2 and pertussis toxin (PTX), the authors showed that the increased $\mathrm{Na}^{+} / \mathrm{K}^{+}$-ATPase activity under hyposmotic stimulation is most probably mediated by G-protein coupled P2Y receptor activation. Thus, increased $\mathrm{Na}^{+} / \mathrm{K}^{+}$ATPase activity of the epithelium during a hyposmotic challenge was prevented when either ATP release or extracellular ATP accumulation was suppressed, or P2Y receptors were inhibited. This result correlated Panx and connexin activities with ATP release, most likely due to the channels' mechanosensitivity (Bao et al., 2004a,b), in response to swelling of the lens cells during the hyposmotic stimulation.

Pannexin/connexin-mediated ATP release during hyposmotic stress was linked to TRPV4 channel activation by Shahidullah et al. (2012). The TRPV4 encoded protein is a $\mathrm{Ca}^{2+}$-permeable, nonselective cation channel that is involved in the regulation of systemic osmotic pressure. Like other members of the TRP superfamily, TRPV channels can be activated through seemingly disparate mechanisms. In the lens epithelium, TRPV4 inhibitors prevented ATP release and propidium iodide uptake of the lens epithelium and an agonist elicited ATP release and propidium iodide uptake even under isosmotic conditions. Similarly, in esophageal epithelial cells it was shown that TRPV4 activation triggers Cx43- and Panx1-mediated ATP release (Ueda et al., 2011), and in the airway epithelium TRPV4 transduced the membrane stretch signal upon leading to hypotonicity-induced, Panx1-mediated ATP release (Seminario-Vidal et al., 2009). Since the TRPV4 channel is permeable for $\mathrm{Ca}^{2+}$ ions, the activation of TRPV4 caused an increase of intracellular $\mathrm{Ca}^{2+}$ in response to the hyposmotic challenge, which was eliminated by the two TRPV4 antagonists and elicited by the agonist under isosmotic conditions. The intracellular $\mathrm{Ca}_{2}{ }^{+}$rise was also prevented when the bathing solution was calcium free. Thus, the $\mathrm{Ca}^{2+}$, which is entering the cells through activated TRPV4 channels during the hyposmotic challenge, might in turn activate Panx1 channels (Locovei et al., 2006b) or connexin hemichannels like Cx32 (De Vuyst et al., 2006) or Cx43 (Retamal et al., 2007). Since inhibition of TRPV4 prevented ATP release during hyposmotic stress, no increased $\mathrm{Na}^{+} / \mathrm{K}^{+}$ATPase activity was evoked. Summing up, the results reported suggest that Panxl together with connexins, ATP and purinergic receptors participates in osmotic regulation, through modulation of $\mathrm{Na}^{+} / \mathrm{K}^{+}$ATPase activity.

Panx1 was also identified in blood endothelial cells of the tunica vasculosa lentis (Dvoriantchikova et al., 2006b), an extensive capillary network deriving from the vasa hyaloidea, spreading over the posterior and lateral surfaces of the lens, which disappears after birth (Skapinker and Rothberg, 1987; Barishak, 1992). There, Panx1 was mostly found at the luminal side of the blood capillaries. No co-localization with Cx50 was detected. 
Panx1 channels, alongside with connexins, are localized in a strategic position alongside connexins with potential to participate in differentiation and lens homeostasis. With Panx1 channels known to play a significant role in cell death, it is tempting to speculate about a role in the retinopathy of prematurity (Pau, 2008). It remains to be demonstrated whether pharmacological blocking of Panxl in patients with this condition can modulate the disproportional regression of the vasa hyaloidea by cell death and the proliferation of retinal vessels, causing fibrovascular tissue to overgrow the remnants of retina-attaching hyaloidal structures through the vitreous cavity up to the tunica vasculosa lentis.

\section{PANX1 AND AQUEOUS HUMOR OUTFLOW: IMPLICATIONS IN GLAUCOMA}

A potential role of Panx1 channels in pressure regulation of the aqueous humor outflow pathway has emerged recently (Li et al., 2010, 2012). Two parallel pathways mediate the outflow of the aqueous humor. In the uveoscleral pathway, aqueous humor is flowing through ciliary muscle bundles and subsequent passage to pressure-insensitive routes (Toris et al., 2008). The pressuresensitive trabecular meshwork pathway comprises the trabecular meshwork, juxtacanalicular tissue, the inner wall of the Schlemm's canal, collector channels and aqueous veins (Gong et al., 1996; Goel et al., 2010). Cells of the outflow pathway are important for the regulation of the outflow, with trabecular meshwork cells playing a critical role (Francis and Alvarado, 1997). Among the substances released by trabecular meshwork cells are components of the extracellular matrix, like metalloproteinases (MMPs) and their inhibitors modeling the extracellular matrix and therewith the outflow resistance (Aga et al., 2008). The release of MMP-2 is regulated by $\mathrm{A} 1$ adenosine receptors on trabecular meshwork cells (Shearer and Crosson, 2002), leading to reduced outflow resistance and reduced intraocular pressure (IOP). Inflow and outflow pressure regulation involves adenosine receptor pathways. The A3 receptor activation enhances the intraocular pressure by activating chloride channels on nonpigmented ciliary epithelial cell that secrete chloride and enhance aqueous humor formation (Mitchell et al., 1999; Avila et al., 2001). Both act in concert and are potential targets to reduce IOP in glaucoma patients. It is tempting to speculate whether a feedback control mechanism exists involving Panx1 released ATP that is metabolized by ecto-ATPases to adenosine (Shearer and Crosson, 2002; Husain et al., 2007). Results that provided first evidence were quantitative RT-PCR experiments demonstrating that $\mathrm{Cx} 26, \mathrm{Cx} 31$ and $\mathrm{Cx} 43$ were expressed in trabecular meshwork cells, with Panx1 and Cx43 being equally expressed in the human trabecular meshwork cell line TM5. In human explant-derived primary trabecular meshwork cells Cx43 levels were 10-fold higher compared to Panx1, whereas the expression of the P2X7-R is about a 100-fold lower. Applying 21 different inhibitors, Li et al. (2010) showed that Panxl channels, connexin hemichannels, and P2X7-R are important in swellingactivated ATP release from trabecular meshwork cells, with Panx1 and connexins accounting for about $40 \%$ each of the released ATP, and P2X7-R for about $16 \%$ or $30 \%$ when Panx 1 and connexin hemichannels were not blocked simultaneously. This supports a role of Panx1, most likely in cooperation with connexins and $\mathrm{P} 2 \mathrm{X} 7-\mathrm{R}$ in modulating the pressure of the outflow pathway.
Further, in the bovine ciliary epithelium, quantitative RT-PCR experiments revealed the expression of Panx1, Cx40, Cx43 and $\mathrm{P} 2 \mathrm{X} 7-\mathrm{R}$ in mixed primary cultures of nonpigmented and pigmented ciliary epithelial cells and transformed nonpigmented and pigmented epithelial cells. Using 11 different inhibitors, Li et al. (2010) showed that in these cells during hypotonicity-triggered ATP release Panx1 and connexins contribute to the ATP release, but that P2X7-R-mediated ATP release was insignificant, whereas $20 \%$ of the ATP release was vesicular.

A role of Panx1 in modulating pressure is potentially of significant clinical relevance. Glaucoma represents a group of ocular disorders with multi-factorial etiology united by a clinically characteristic IOP associated optic neuropathy and is a leading cause for blindness. The treatment that delays the onset and slows the progression of glaucomatous blindness is reducing IOP. Evidence is accruing that Panxl might be directly involved in the pathology of glaucoma. It has been shown that ATP levels are elevated with increased IOP (Resta et al., 2007; Li et al., 2011), even in correlation with the magnitude of increased pressure in the vitreous of patients with acute angle closure glaucoma (Zhang et al., 2007). It has been hypothesized that excess extracellular ATP might lead to neuronal death, since stimulation of P2X7-R on RGCs leads to an increase of the cytosolic $\mathrm{Ca}^{2+}$ concentration with subsequent excitotoxic cell death (Zhang et al., 2005). The P2X7-R is of special importance, as the receptor can also initiate inflammatory responses, which play a role in glaucoma (reviewed in Krizaj et al., 2014). Also, RGCs were rescued during rapidly increased ocular pressure by apyrase-mediated dephosphorylation of ATP and by inhibiting purinergic receptors (Resta et al., 2007). In accordance, mechanical perturbations, e.g., due to increased hydrostatic pressure, cell swelling or stretching, shear stress, are most efficiently triggering ATP release (discussed in Reigada et al., 2008). One study linked a possible involvement of Panxl in glaucoma pathogenesis (Reigada et al., 2008) to Panxl as a mechanosensitive ATP-release channel (Bao et al., 2004a,b). Using ex vivo bovine eyecup preparations, the authors showed that $10 \mathrm{~min}$ of increased pressure of $20 \mathrm{mmHg}$ above the atmospheric pressure led to physiological ATP release in the vitreal chamber that declined back to the baseline within $30 \mathrm{~min}$. In contrast, applying 70 $\mathrm{mmHg}$ led to a constant increase of the ATP levels throughout a 60 min experiment. Furthermore, the authors demonstrated that the amount of ATP strongly correlated with the applied pressure. Carbenoxolone, 5-nitro-2-(3-phenylpropylamino) benzoic acid (NPPB; Silverman et al., 2008), but not mefloquine, reduced the ATP release by about $90 \%$, leading to the author's conclusion of a Panx1-mediated ATP release. Since mefloquine efficiently inhibits Panxl channel in the $\mathrm{nM}$ concentration range (Iglesias et al., 2009b), but failed to reduce the pressure-induced ATPincrease in this study, the results raise the question whether connexin hemichannels or other ATP release mechanisms, like vesicular release were involved. Further, NPPB can inhibit other channels that have been associated with ATP release (discussed in Reigada et al., 2008), like volume sensitive channels (Furukawa et al., 1998), voltage-dependent anion channels (VDAC; Sabirov et al., 2001) and the cystic fibrosis transmembrane conductance regulator (CFTR; Cuthbert, 2001). Using isolated rat RGCs and applying blocker pharmacology, a subsequent study proved that 
RGCs themselves mediate mechanosensitive ATP release, as they respond upon bathing in hypotonic solutions to swelling-induced mechanical stress with rapid and sustained Panx1-mediated ATP release, which in turn autostimulates P2X7-R on RGCs (Xia et al., 2012). In mixed retinal cultures, the hypotonicity-induced ATP levels rapidly rose to a transient peak and afterwards declined to a steady state, indicating a higher rate of ATP breakdown than ATP release. In contrast, in isolated RGCs the ATP levels constantly rose during the recording time, indicating less ectoATPase activity compared to the mixed cultures. Also, stretching mixed retinal cells or isolated RGCs lead to ATP release in a Panx1-dependent manner. Subsequent whole-cell patch clamp recordings from RGCs in mixed retinal cultures and isolated RGCs revealed that swelling induced ATP release activates P2X7$\mathrm{R}$ on RGCs. In turn, the ecto-ATPase apyrase, probenecide or carbenoxolone or the P2X7-R antagonists A438079, AZ 10606120 and zinc reduced the swelling-activated currents. Since Panx 1 and P2X7-R are expressed on RGC neurites, Xia et al. (2012) reasoned that the ATP release and $\mathrm{P} 2 \mathrm{X} 7-\mathrm{R}$ autostimulation take place in the RGC axons. These results are unexpected, since other studies have shown that increased IOP first affects the dendritic field size, number of synapses, light-evoked responses and leads to abnormalities in dendritic arbors prior to a reduction of axon thickness and deformation of the optic nerve head (reviewed in Krizaj et al., 2014). Interestingly, Panx1-mediated ATP release seems to be important for RGCs cells for their regulatory volume decrease. Under control conditions during bathing in hypotonic solution, the RGCs initially swell to a peak size, but after $30 \mathrm{~min}$ decrease their volume again due to regulatory volume decrease, which was reduced by about $60 \%$ when probenecide was applied, indicating a beneficial contribution of Panxl channels in this context. Still, in an event of chronic increased IOP, Panx1 may mediate the release of excessive ATP amounts leading to harmful autocrine stimulation of P2X7-R that drives the whole system in a pathological state, leading to the P2X7-R/Panx1 "deathcomplex". Thus, in accordance with being localized on neurites, this putative damaging signaling pathway can cause RGC death by damaging axonal processes, a possible mechanism in glaucoma pathology. A novel finding is that astrocytes isolated from optic nerve heads upregulated Panxl expression and increased ATP release with sustained stretch (Beckel et al., 2014). This suggested a glia cell based mechanism for maintaining elevated extracellular ATP upon sustained pressure induced mechanical strain. Further, Beckel et al. concluded that physiological consequences could be either beneficial or detrimental for RGCs, depending on the relative levels of adenosine or P2X7-R/Panx1. Other mechanosensitive (like TRPV4) or inflammatory factors in glaucoma exist and have been recently reviewed (Krizaj et al., 2014).

\section{PANX1 IN THE CORNEA: IMPLICATIONS FOR WOUND HEALING}

IHC experiments revealed that Panx1 is also expressed in the cornea of mice (Mayo et al., 2008). In this study, the primary purpose was to analyze the role of P2X7-R in the repair of in vivo corneal epithelial debridement wounds and in the structural organization on the corneal stroma. After epithelial debridement was performed on $\mathrm{P} 2 \mathrm{X} 7-\mathrm{R}^{-/-}$and wild-type mice, light microscopic, immunohistochemical, and electron microscopic analysis showed that Panx1 was localized between cells with a certain distance distal to the leading edge of epithelial debridement of mice corneas. In contrast, Panxl was detected throughout the epithelium and at the leading edge of the injury in WT animals. This indicated that the absence of P2X7-R alters the localization of Panx1 in the cornea. Further, in $\mathrm{P} 2 \mathrm{X} 7^{-/-}$mice the rate of wound repair was negatively affected. The absence of Panxl at the wound edge is in line with another study about Panx1 in skin development and wound healing (Penuela et al., 2014a).

\section{CHALLENGES IN PANNEXIN RESEARCH}

Research addressing the (patho)physiological roles of Panxl needs to overcome biological, technical and logistical challenges. A significant biological challenge derives from the complex interactions of Panxl with major signaling pathways involving ionotropic and metabotropic receptors (Isakson and Thompson, 2014), the inflammasome (Adamson and Leitinger, 2014) cell death pathway (Jackson et al., 2014), or the cytoskeleton (Boyce et al., 2014). The capacity of Panx1 to undergo multiple interactions is exciting, suggesting clinically relevant roles in many physiological and pathophysiological settings. Dissecting complex networks of interactions has high priority and will guide our understanding of the (patho)physiology of Panx1 in the eye and beyond.

Pharmacological manipulation of Panx1 is a second challenge despite the significant advances made in recent years. Blocking peptides like ${ }^{10}$ Panx1 (Pelegrin and Surprenant, 2006), peptides interfering with Panx1 in a specific context like anoxia (Weilinger et al., 2012), or pharmacological blockers like probenecid (Silverman et al., 2008), mefloquine (Iglesias et al., 2009b), or more recently the food dye FD\&C Blue No. 1 (Wang et al., 2013) have greatly improved our understanding of Panxl. These studies were mostly performed in the context of single cell types or oocytes and all compounds used acted by closing the Panx1 channel. However, it might be beneficial in certain conditions to open Panx1 channels when ATP efflux is needed. Further, there is a demand for selective agonists/antagonists to discriminate between the three Panx channels and connexin hemichannels frequently co-expressed in complex tissues like the eye.

The availability of Panx1 KO mouse models has greatly contributed to the understanding of Panxl functions in vivo. A challenge emerging from mouse models and $\mathrm{KO}$ cell lines is the question of compensatory upregulation of other Panxs or connexin hemichannels. Recently, Panx3 has been shown to be upregulated in the arterial walls and skin of Panx1 knock out mice (Lohman and Isakson, 2014; Penuela et al., 2014a). In case compensatory regulation is more common, proving functional compensation will critically depend on specific blockers not available at present. Rational designed drugs to selectively target Panx proteins could derive from mimetic peptides with less crossinhibition or pharmacological screens of natural compounds (Grek et al., 2014; Saez and Leybaert, 2014).

Dissecting complex interactions and solving pharmacological shortcomings are of general concern. A specific concern for vision 
and eye research is choosing appropriate animal models. While vertebrate eyes share a general anatomy and physiology, visual capabilities are distinct, frequently reflecting functional adaptations to habitats and/or behaviors. Complementary models are needed to weight advantages over disadvantages of each species when investigating the roles of Panxs in the eye. Already distinct functional roles of Panx1 in the mouse and zebrafish retina have emerged, reflecting unique properties of the two species (Kranz et al., 2013; Vroman et al., 2014). Beyond doubt, studies in mouse and fish models have and will aid our understanding of fundamental roles of Panx1 in the visual system, but to build a more generalized view of Panx functions complementary studies in other higher vertebrates like rats and rabbits, or in color vision competent non-human primates will be needed. Recent advances in genome engineering technologies based on transcription activator-like effector nucleases (TALEN) or the RNA-guided Cas9 nuclease (Cas9/CRISPR) have been successfully used to generate first functional knock downs or knock outs in a wide range of species including non-human primates (Mali et al., 2013a,b; Liu et al., 2014a,b; Niu et al., 2014; Yang et al., 2014) making targeting Panx1 in higher vertebrates an experimental option.

\section{CONCLUDING REMARKS}

Panx1 research in the eye has moved from early expression and localization studies to functional studies. This research is currently driven by the availability of knock out animal models, sophisticated ex vivo and in vitro preparations suitable to address the emerging roles of Panx1 in a physiological or pathological context, and the potential implication of Panx1 in leading causes of blindness. There is no confirmed unifying theme to be highlighted yet. Instead, we wish to communicate that Panx1 channels are highly versatile channels. Functions are mediated by the distinct localization of Panx1 proteins in different cell types, multiple protein interactions, as well as post-translational modifications. Since Panxl channels operate at the crossroad of major signaling pathways, it is tempting to speculate that long lasting changes to this channel have the potential to impact physiological functions by altering major signaling pathways. ATP release, as found in the humor outflow system or as a mediator of cross talk between neurons and microglia, has the potential to be the unifying molecular function, connecting biophysical properties of Panxl channels to ATP mediated signaling. However, this generalization might not be fully true. Bipolar cells like CB3a cells do not release ATP in any known physiological or pathological context. Further, HC release ATP, but it is the $\mathrm{pH}$ shift evoked by the breakdown of ATP to adenosine that alters neuronal communication. Since insight into the relevant molecular, cellular and physiological roles of Panx1 in conditions as diverse as primary processing of visual information in the outer retina or IOP regulation is emerging, we expect soon advances in conceptual insight related to the different roles of Panx1 in this physiologically and clinically important sensory organ.

\section{ACKNOWLEDGMENTS}

This work was supported by CRC/CIHR and NSERC-DG.

\section{REFERENCES}

Adamson, S. E., and Leitinger, N. (2014). The role of pannexin1 in the induction and resolution of inflammation. FEBS Lett. 588, 1416-1422. doi: 10.1016/j. febslet.2014.03.009

Aga, M., Bradley, J. M., Keller, K. E., Kelley, M. J., and Acott, T. S. (2008). Specialized podosome- or invadopodia-like structures (PILS) for focal trabecular meshwork extracellular matrix turnover. Invest. Ophthalmol. Vis. Sci. 49, 5353 5365. doi: 10.1167/iovs.07-1666

Avila, M. Y., Stone, R. A., and Civan, M. M. (2001). A(1)-, A(2A)- and A(3)subtype adenosine receptors modulate intraocular pressure in the mouse. $\mathrm{Br}$. J. Pharmacol. 134, 241-245. doi: 10.1038/sj.bjp.0704267

Bao, Y., Chen, Y., Ledderose, C., Li, L., and Junger, W. G. (2013). Pannexin 1 channels link chemoattractant receptor signaling to local excitation and global inhibition responses at the front and back of polarized neutrophils. J. Biol. Chem. 288, 22650-22657. doi: 10.1074/jbc.m113.476283

Bao, L., Locovei, S., and Dahl, G. (2004a). Pannexin membrane channels are mechanosensitive conduits for ATP. FEBS Lett. 572, 65-68. doi: 10.1016/j. febslet.2004.07.009

Bao, L., Sachs, F., and Dahl, G. (2004b). Connexins are mechanosensitive. Am. J. Physiol. Cell Physiol. 287, C1389-C1395. doi: 10.1152/ajpcell.00220.2004

Baranova, A., Ivanov, D., Petrash, N., Pestova, A., Skoblov, M., Kelmanson, I., et al. (2004). The mammalian pannexin family is homologous to the invertebrate innexin gap junction proteins. Genomics 83, 706-716. doi: 10.1016/j.ygeno.2003. 09.025

Barishak, Y. R. (1992). Embryology of the eye and its adnexae. Dev. Ophthalmol. 24, $1-142$.

Beckel, J. M., Argall, A. J., Lim, J. C., Xia, J., Lu, W., Coffey, E. E., et al. (2014). Mechanosensitive release of adenosine $5^{\prime}$-triphosphate through pannexin channels and mechanosensitive upregulation of pannexin channels in optic nerve head astrocytes: a mechanism for purinergic involvement in chronic strain. Glia 62, 1486-1501. doi: 10.1002/glia.22695

Berthoud, V. M., Minogue, P. J., Osmolak, P., Snabb, J. I., and Beyer, E. C. (2014). Roles and regulation of lens epithelial cell connexins. FEBS Lett. 588, 1297-1303. doi: 10.1016/j.febslet.2013.12.024

Beyer, E. C., and Berthoud, V. M. (2014). Connexin hemichannels in the lens. Front. Physiol. 5:20. doi: 10.3389/fphys.2014.00020

Bloomfield, S. A., Xin, D., and Persky, S. E. (1995). A comparison of receptive field and tracer coupling size of horizontal cells in the rabbit retina. Vis. Neurosci. 12, 985-999. doi: 10.1017/s0952523800009524

Boassa, D., Ambrosi, C., Qiu, F., Dahl, G., Gaietta, G., and Sosinsky, G. (2007). Pannexin1 channels contain a glycosylation site that targets the hexamer to the plasma membrane. J. Biol. Chem. 282, 31733-31743. doi: 10.1074/jbc. m702422200

Bond, S. R., and Naus, C. C. (2014). The pannexins: past and present. Front. Physiol. 5:58. doi: 10.3389/fphys.2014.00058

Bond, S. R., Wang, N., Leybaert, L., and Naus, C. C. (2012). Pannexin 1 ohnologs in the teleost lineage. J. Membr. Biol. 245, 483-493. doi: 10.1007/s00232-0129497-4

Boyce, A. K., Wicki-Stordeur, L. E., and Swayne, L. A. (2014). Powerful partnership: crosstalk between pannexin 1 and the cytoskeleton. Front. Physiol. 5:27. doi: 10 . 3389/fphys.2014.00027

Bruzzone, R., Barbe, M. T., Jakob, N. J., and Monyer, H. (2005). Pharmacological properties of homomeric and heteromeric pannexin hemichannels expressed in Xenopus oocytes. J. Neurochem. 92, 1033-1043. doi: 10.1111/j.1471-4159.2004. 02947.x

Bruzzone, R., Hormuzdi, S. G., Barbe, M. T., Herb, A., and Monyer, H. (2003). Pannexins, a family of gap junction proteins expressed in brain. Proc. Natl. Acad. Sci. U S A 100, 13644-13649. doi: 10.1073/pnas.2233464100

Burkhardt, D. A., and Fahey, P. K. (1998). Contrast enhancement and distributed encoding by bipolar cells in the retina. J. Neurophysiol. 80, 1070-1081.

Celetti, S. J., Cowan, K. N., Penuela, S., Shao, Q., Churko, J., and Laird, D. W. (2010). Implications of pannexin 1 and pannexin 3 for keratinocyte differentiation. J. Cell Sci. 123, 1363-1372. doi: 10.1242/jcs.056093

Conway, B. R. (2007). Color vision: mice see hue too. Curr. Biol. 17, R457-R460. doi: 10.1016/j.cub.2007.04.017

Cuthbert, A. W. (2001). Assessment of CFTR chloride channel openers in intact normal and cystic fibrosis murine epithelia. Br. J. Pharmacol. 132, 659-668. doi: 10.1038/sj.bjp.0703859 
Dahl, G., and Keane, R. W. (2012). Pannexin: from discovery to bedside in 11+/-4 years? Brain Res. 1487, 150-159. doi: 10.1016/j.brainres.2012.04.058

Dando, R., and Roper, S. D. (2009). Cell-to-cell communication in intact taste buds through ATP signalling from pannexin 1 gap junction hemichannels. J. Physiol. 587, 5899-5906. doi: 10.1113/jphysiol.2009.180083

Davalos, D., Grutzendler, J., Yang, G., Kim, J. V., Zuo, Y., Jung, S., et al. (2005). ATP mediates rapid microglial response to local brain injury in vivo. Nat. Neurosci. 8, 752-758. doi: 10.1038/nn1472

Delamere, N. A., and Tamiya, S. (2009). Lens ion transport: from basic concepts to regulation of Na,K-ATPase activity. Exp. Eye Res. 88, 140-143. doi: 10.1016/j. exer.2008.05.005

de Rivero Vaccari, J. P., Lotocki, G., Alonso, O. F., Bramlett, H. M., Dietrich, W. D., Keane, R. W., et al. (2009). Therapeutic neutralization of the NLRP1 inflammasome reduces the innate immune response and improves histopathology after traumatic brain injury. J. Cereb. Blood Flow Metab. 29, 1251-1261. doi: 10. 1038/jcbfm.2009.46

De Vuyst, E., Decrock, E., Cabooter, L., Dubyak, G. R., Naus, C. C., Evans, W. H., et al. (2006). Intracellular calcium changes trigger connexin 32 hemichannel opening. EMBO J. 25, 34-44. doi: 10.1038/sj.emboj.7600908

D’hondt, C., Iyyathurai, J., Vinken, M., Rogiers, V., Leybaert, L., Himpens, B., et al. (2013). Regulation of connexin- and pannexin-based channels by posttranslational modifications. Biol. Cell 105, 373-398. doi: 10.1111/boc.20120 0096

Domercq, M., Vazquez-Villoldo, N., and Matute, C. (2013). Neurotransmitter signaling in the pathophysiology of microglia. Front. Cell. Neurosci. 7:49. doi: 10. 3389/fncel.2013.00049

Dvoriantchikova, G., Ivanov, D., Barakat, D., Grinberg, A., Wen, R., Slepak, V. Z., et al. (2012). Genetic ablation of Pannexinl protects retinal neurons from ischemic injury. PLoS One 7:e31991. doi: 10.1371/journal.pone.003 1991

Dvoriantchikova, G., Ivanov, D., Panchin, Y., and Shestopalov, V. I. (2006a). Expression of pannexin family of proteins in the retina. FEBS Lett. 580, 21782182. doi: 10.1016/j.febslet.2006.03.026

Dvoriantchikova, G., Ivanov, D., Pestova, A., and Shestopalov, V. (2006b). Molecular characterization of pannexins in the lens. Mol. Vis. 12, 1417-1426.

Fahrenfort, I., Steijaert, M., Sjoerdsma, T., Vickers, E., Ripps, H., van Asselt, J., et al. (2009). Hemichannel-mediated and pH-based feedback from horizontal cells to cones in the vertebrate retina. PLoS One 4:e6090. doi: 10.1371/journal.pone. 0006090

Fontainhas, A. M., Wang, M., Liang, K. J., Chen, S., Mettu, P., Damani, M., et al. (2011). Microglial morphology and dynamic behavior is regulated by ionotropic glutamatergic and GABAergic neurotransmission. PLoS One 6:e15973. doi: 10. 1371/journal.pone.0015973

Francis, B. A., and Alvarado, J. (1997). The cellular basis of aqueous outflow regulation. Curr. Opin. Ophthalmol. 8, 19-27. doi: 10.1097/00055735-19970400000005

Furukawa, T., Ogura, T., Katayama, Y., and Hiraoka, M. (1998). Characteristics of rabbit ClC-2 current expressed in Xenopus oocytes and its contribution to volume regulation. Am. J. Physiol. 274, C500-C512.

Goel, M., Picciani, R. G., Lee, R. K., and Bhattacharya, S. K. (2010). Aqueous humor dynamics: a review. Open Ophthalmol. J. 4, 52-59. doi: 10.2174/ 1874364101004010052

Goldsmith, P., and Harris, W. A. (2003). The zebrafish as a tool for understanding the biology of visual disorders. Semin. Cell Dev. Biol. 14, 11-18. doi: 10. 1016/s1084-9521(02)00167-2

Gong, H., Tripathi, R. C., and Tripathi, B. J. (1996). Morphology of the aqueous outflow pathway. Microsc. Res. Tech. 33, 336-367. doi: 10.1002/(sici)10970029(19960301)33:4<336::aid-jemt4>3.0.co;2-n

Grek, C. L., Rhett, J. M., and Ghatnekar, G. S. (2014). Cardiac to cancer: connecting connexins to clinical opportunity. FEBS Lett. 588, 1349-1364. doi: 10.1016/j. febslet.2014.02.047

Hagins, W. A., Penn, R. D., and Yoshikami, S. (1970). Dark current and photocurrent in retinal rods. Biophys. J. 10, 380-412. doi: 10.1016/s0006-3495(70) 86308-1

Hanner, F., Lam, L., Nguyen, M. T., Yu, A., and Peti-Peterdi, J. (2012). Intrarenal localization of the plasma membrane ATP channel pannexin1. Am. J. Physiol. Renal Physiol. 303, F1454-F1459. doi: 10.1152/ajprenal.00206.2011

Hirasawa, H., Yamada, M., and Kaneko, A. (2012). Acidification of the synaptic cleft of cone photoreceptor terminal controls the amount of transmitter release, thereby forming the receptive field surround in the vertebrate retina. J. Physiol. Sci. 62, 359-375. doi: 10.1007/s12576-012-0220-0

Huang, Y., Grinspan, J. B., Abrams, C. K., and Scherer, S. S. (2007a). Pannexin1 is expressed by neurons and glia but does not form functional gap junctions. Glia 55, 46-56. doi: 10.1002/glia.20435

Huang, Y. J., Maruyama, Y., Dvoryanchikov, G., Pereira, E., Chaudhari, N., and Roper, S. D. (2007b). The role of pannexin 1 hemichannels in ATP release and cell-cell communication in mouse taste buds. Proc. Natl. Acad. Sci. U S A 104, 6436-6441. doi: 10.1073/pnas.0611280104

Husain, S., Shearer, T. W., and Crosson, C. E. (2007). Mechanisms linking adenosine $\mathrm{A} 1$ receptors and extracellular signal-regulated kinase $1 / 2$ activation in human trabecular meshwork cells. J. Pharmacol. Exp. Ther. 320, 258-265. doi: $10.1124 /$ jpet.106.110981

Iglesias, R., Dahl, G., Qiu, F., Spray, D. C., and Scemes, E. (2009a). Pannexin 1: the molecular substrate of astrocyte "hemichannels". J. Neurosci. 29, 7092-7097. doi: 10.1523/jneurosci.6062-08.2009

Iglesias, R., Spray, D. C., and Scemes, E. (2009b). Mefloquine blockade of Pannexin1 currents: resolution of a conflict. Cell Commun. Adhes. 16, 131-137. doi: $10.3109 / 15419061003642618$

Isakson, B. E., and Thompson, R. J. (2014). Pannexin-1 as a potentiator of ligandgated receptor signaling. Channels (Austin) 8, 118-123. doi: 10.4161/chan. 27978

Jackman, S. L., Babai, N., Chambers, J. J., Thoreson, W. B., and Kramer, R. H. (2011). A positive feedback synapse from retinal horizontal cells to cone photoreceptors. PLoS Biol. 9:e1001057. doi: 10.1371/journal.pbio.1001057

Jackson, D. G., Wang, J., Keane, R. W., Scemes, E., and Dahl, G. (2014). ATP and potassium ions: a deadly combination for astrocytes. Sci. Rep. 4:4576. doi: 10. 1038/srep04576

Jaillon, O., Aury, J. M., Brunet, F., Petit, J. L., Stange-Thomann, N., Mauceli, E., et al. (2004). Genome duplication in the teleost fish Tetraodon nigroviridis reveals the early vertebrate proto-karyotype. Nature 431, 946-957. doi: 10. 1038/nature 03025

Johnstone, S. R., Billaud, M., Lohman, A. W., Taddeo, E. P., and Isakson, B. E. (2012). Posttranslational modifications in connexins and pannexins. J. Membr. Biol. 245, 319-332. doi: 10.1007/s00232-012-9453-3

Kamermans, M., and Fahrenfort, I. (2004). Ephaptic interactions within a chemical synapse: hemichannel-mediated ephaptic inhibition in the retina. Curr. Opin. Neurobiol. 14, 531-541. doi: 10.1016/j.conb.2004.08.016

Kamermans, M., Fahrenfort, I., Schultz, K., Janssen-Bienhold, U., Sjoerdsma, T., and Weiler, R. (2001). Hemichannel-mediated inhibition in the outer retina. Science 292, 1178-1180. doi: 10.1126/science.1060101

Kanneganti, T. D., Lamkanfi, M., Kim, Y. G., Chen, G., Park, J. H., Franchi, L., et al. (2007). Pannexin-1-mediated recognition of bacterial molecules activates the cryopyrin inflammasome independent of toll-like receptor signaling. Immunity 26, 433-443. doi: 10.1016/j.immuni.2007.03.008

Karatas, H., Erdener, S. E., Gursoy-Ozdemir, Y., Lule, S., Eren-Kocak, E., Sen, Z. D., et al. (2013). Spreading depression triggers headache by activating neuronal Panx1 channels. Science 339, 1092-1095. doi: 10.1126/science.1231897

Kawamura, M. Jr., Ruskin, D. N., and Masino, S. A. (2010). Metabolic autocrine regulation of neurons involves cooperation among pannexin hemichannels, adenosine receptors and KATP channels. J. Neurosci. 30, 3886-3895. doi: 10. 1523/JNEUROSCI.0055-10.2010

Kienitz, M. C., Bender, K., Dermietzel, R., Pott, L., and Zoidl, G. (2011). Pannexin 1 constitutes the large conductance cation channel of cardiac myocytes. J. Biol. Chem. 286, 290-298. doi: 10.1074/jbc.M110.163477

Kim, J. E., and Kang, T. C. (2011). The P2X7 receptor-pannexin-1 complex decreases muscarinic acetylcholine receptor-mediated seizure susceptibility in mice. J. Clin. Invest. 121, 2037-2047. doi: 10.1172/JCI44818

Klaassen, L. J., Fahrenfort, I., and Kamermans, M. (2012). Connexin hemichannel mediated ephaptic inhibition in the retina. Brain Res. 1487, 25-38. doi: 10. 1016/j.brainres.2012.04.059

Klaassen, L. J., Sun, Z., Steijaert, M. N., Bolte, P., Fahrenfort, I., Sjoerdsma, T., et al. (2011). Synaptic transmission from horizontal cells to cones is impaired by loss of connexin hemichannels. PLoS Biol. 9:e1001107. doi: 10.1371/journal. pbio. 1001107

Kranz, K., Dorgau, B., Pottek, M., Herrling, R., Schultz, K., Bolte, P., et al. (2013). Expression of Pannexin1 in the outer plexiform layer of the mouse retina and physiological impact of its knockout. J. Comp. Neurol. 521, 1119-1135. doi: 10. $1002 /$ cne. 23223 
Krizaj, D., Ryskamp, D. A., Tian, N., Tezel, G., Mitchell, C. H., Slepak, V. Z., et al. (2014). From mechanosensitivity to inflammatory responses: new players in the pathology of glaucoma. Curr. Eye Res. 39, 105-119. doi: 10.3109/02713683.2013. 836541

Kronlage, M., Song, J., Sorokin, L., Isfort, K., Schwerdtle, T., Leipziger, J., et al. (2010). Autocrine purinergic receptor signaling is essential for macrophage chemotaxis. Sci. Signal. 3:ra55. doi: 10.1126/scisignal.2000588

Kurtenbach, S., Prochnow, N., Kurtenbach, S., Klooster, J., Zoidl, C., Dermietzel, R., et al. (2013). Pannexinl channel proteins in the zebrafish retina have shared and unique properties. PLoS One 8:e77722. doi: 10.1371/journal.pone.00 77722

Lai, C. P., Bechberger, J. F., Thompson, R. J., Macvicar, B. A., Bruzzone, R., and Naus, C. C. (2007). Tumor-suppressive effects of pannexin 1 in C6 glioma cells. Cancer Res. 67, 1545-1554. doi: 10.1158/0008-5472.can-06-1396

Lamkanfi, M., Malireddi, R. K., and Kanneganti, T. D. (2009). Fungal zymosan and mannan activate the cryopyrin inflammasome. J. Biol. Chem. 284, 20574-20581. doi: 10.1074/jbc.m109.023689

Lee, J. E., Liang, K. J., Fariss, R. N., and Wong, W. T. (2008). Ex vivo dynamic imaging of retinal microglia using time-lapse confocal microscopy. Invest. Ophthalmol. Vis. Sci. 49, 4169-4176. doi: 10.1167/iovs.08-2076

Li, A., Leung, C. T., Peterson-Yantorno, K., Mitchell, C. H., and Civan, M. M. (2010). Pathways for ATP release by bovine ciliary epithelial cells, the initial step in purinergic regulation of aqueous humor inflow. Am. J. Physiol. Cell Physiol. 299, C1308-C1317. doi: 10.1152/ajpcell.00333.2010

Li, A., Leung, C. T., Peterson-Yantorno, K., Stamer, W. D., Mitchell, C. H., and Civan, M. M. (2012). Mechanisms of ATP release by human trabecular meshwork cells, the enabling step in purinergic regulation of aqueous humor outflow. J. Cell. Physiol. 227, 172-182. doi: 10.1002/jcp.22715

Li, A., Zhang, X., Zheng, D., Ge, J., Laties, A. M., and Mitchell, C. H. (2011). Sustained elevation of extracellular ATP in aqueous humor from humans with primary chronic angle-closure glaucoma. Exp. Eye Res. 93, 528-533. doi: 10. 1016/j.exer.2011.06.020

Liang, J., Takeuchi, H., Jin, S., Noda, M., Li, H., Doi, Y., et al. (2010). Glutamate induces neurotrophic factor production from microglia via protein kinase $\mathrm{C}$ pathway. Brain Res. 1322, 8-23. doi: 10.1016/j.brainres.2010.01.083

Liu, H., Chen, Y., Niu, Y., Zhang, K., Kang, Y., Ge, W., et al. (2014a). TALENmediated gene mutagenesis in rhesus and cynomolgus monkeys. Cell Stem Cell 14, 323-328. doi: 10.1016/j.stem.2014.01.018

Liu, Z., Zhou, X., Zhu, Y., Chen, Z. F., Yu, B., Wang, Y., et al. (2014b). Generation of a monkey with MECP2 mutations by TALEN-based gene targeting. Neurosci. Bull. 30, 381-386. doi: 10.1007/s12264-014-1434-8

Locovei, S., Bao, L., and Dahl, G. (2006a). Pannexin 1 in erythrocytes: function without a gap. Proc. Natl. Acad. Sci. U S A 103, 7655-7659. doi: 10.1073/pnas. 0601037103

Locovei, S., Wang, J., and Dahl, G. (2006b). Activation of pannexin 1 channels by ATP through P2Y receptors and by cytoplasmic calcium. FEBS Lett. 580, 239244. doi: 10.1016/j.febslet.2005.12.004

Lohman, A. W., Billaud, M., and Isakson, B. E. (2012a). Mechanisms of ATP release and signalling in the blood vessel wall. Cardiovasc. Res. 95, 269-280. doi: 10. 1093/cvr/cvs187

Lohman, A. W., and Isakson, B. E. (2014). Differentiating connexin hemichannels and pannexin channels in cellular ATP release. FEBS Lett. 588, 1379-1388. doi: 10.1016/j.febslet.2014.02.004

Lohman, A. W., Weaver, J. L., Billaud, M., Sandilos, J. K., Griffiths, R., Straub, A. C., et al. (2012b). S-nitrosylation inhibits pannexin 1 channel function. J. Biol. Chem. 287, 39602-39612. doi: 10.1074/jbc.m112.397976

MacVicar, B. A., and Thompson, R. J. (2010). Non-junction functions of pannexin1 channels. Trends Neurosci. 33, 93-102. doi: 10.1016/j.tins.2009.11.007

Madry, C., Haglerod, C., and Attwell, D. (2010). The role of pannexin hemichannels in the anoxic depolarization of hippocampal pyramidal cells. Brain 133, 37553763. doi: 10.1093/brain/awq284

Mali, P., Esvelt, K. M., and Church, G. M. (2013a). Cas9 as a versatile tool for engineering biology. Nat. Methods 10, 957-963. doi: 10.1038/nmeth.2649

Mali, P., Yang, L., Esvelt, K. M., Aach, J., Guell, M., Dicarlo, J. E., et al. (2013b). RNA-guided human genome engineering via Cas9. Science 339, 823-826. doi: 10.1126/science.1232033

Mayo, C., Ren, R., Rich, C., Stepp, M. A., and Trinkaus-Randall, V. (2008). Regulation by P2X7: epithelial migration and stromal organization in the cornea. Invest. Ophthalmol. Vis. Sci. 49, 4384-4391. doi: 10.1167/iovs.08-1688
Mertsch, K., Hanisch, U. K., Kettenmann, H., and Schnitzer, J. (2001). Characterization of microglial cells and their response to stimulation in an organotypic retinal culture system. J. Comp. Neurol. 431, 217-227. doi: 10.1002/10969861(20010305)431:2<217::aid-cne1066>3.3.co;2-k

Minkiewicz, J., De Rivero Vaccari, J. P., and Keane, R. W. (2013). Human astrocytes express a novel NLRP2 inflammasome. Glia 61, 1113-1121. doi: 10.1002/glia. 22499

Mitchell, C. H., Peterson-Yantorno, K., Carre, D. A., Mcglinn, A. M., Coca-Prados, M., Stone, R. A., et al. (1999). A3 adenosine receptors regulate Cl- channels of nonpigmented ciliary epithelial cells. Am. J. Physiol. 276, C659-C666.

Monaco, E. A. 3rd, and Friedlander, R. M. (2012). A novel target for ischemic stroke therapy: pannexins. Neurosurgery 70, N13-N14. doi: 10.1227/01.neu. 0000413220.21264.df

Mylvaganam, S., Zhang, L., Wu, C., Zhang, Z. J., Samoilova, M., Eubanks, J., et al. (2010). Hippocampal seizures alter the expression of the pannexin and connexin transcriptome. J. Neurochem. 112, 92-102. doi: 10.1111/j.1471-4159. 2009.06431.x

Nimmerjahn, A., Kirchhoff, F., and Helmchen, F. (2005). Resting microglial cells are highly dynamic surveillants of brain parenchyma in vivo. Science 308, 13141318. doi: 10.1126/science. 1110647

Niu, Y., Shen, B., Cui, Y., Chen, Y., Wang, J., Wang, L., et al. (2014). Generation of gene-modified cynomolgus monkey via Cas9/RNA-mediated gene targeting in one-cell embryos. Cell 156, 836-843. doi: 10.1016/j.cell.2014.01.027

Orellana, J. A., Velasquez, S., Williams, D. W., Saez, J. C., Berman, J. W., and Eugenin, E. A. (2013). Pannexin 1 hemichannels are critical for HIV infection of human primary CD4+ T lymphocytes. J. Leukoc. Biol. 94, 399-407. doi: 10. 1189/jlb.0512249

Panchin, Y., Kelmanson, I., Matz, M., Lukyanov, K., Usman, N., and Lukyanov, S. (2000). A ubiquitous family of putative gap junction molecules. Curr. Biol. 10, R473-R474. doi: 10.1016/s0960-9822(00)00576-5

Pau, H. (2008). Retinopathy of prematurity: clinic and pathogenesis. Disproportion between apoptosis of vitreal and proliferation of retinal vascularization. Ophthalmologica 222, 220-224. doi: 10.1159/000130069

Peichl, L., and Gonzalez-Soriano, J. (1993). Unexpected presence of neurofilaments in axon-bearing horizontal cells of the mammalian retina. J. Neurosci. 13, 40914100. doi: 10.1098/rspb.1993.0051

Pelegrin, P., and Surprenant, A. (2006). Pannexin-1 mediates large pore formation and interleukin-1beta release by the ATP-gated P2X7 receptor. EMBO J. 25, 5071-5082. doi: 10.1038/sj.emboj.7601378

Penn, R. D., and Hagins, W. A. (1969). Signal transmission along retinal rods and the origin of the electroretinographic a-wave. Nature 223, 201-204. doi: 10. 1038/223201a0

Penuela, S., Bhalla, R., Gong, X. Q., Cowan, K. N., Celetti, S. J., Cowan, B. J., et al. (2007). Pannexin 1 and pannexin 3 are glycoproteins that exhibit many distinct characteristics from the connexin family of gap junction proteins. J. Cell Sci. 120, 3772-3783. doi: 10.1242/jcs.009514

Penuela, S., Gyenis, L., Ablack, A., Churko, J. M., Berger, A. C., Litchfield, D. W., et al. (2012). Loss of pannexin 1 attenuates melanoma progression by reversion to a melanocytic phenotype. J. Biol. Chem. 287, 29184-29193. doi: 10.1074/jbc. m112.377176

Penuela, S., Kelly, J. J., Churko, J. M., Barr, K. J., Berger, A. C., and Laird, D. W. (2014a). Panxl regulates cellular properties of keratinocytes and dermal fibroblasts in skin development and wound healing. J. Invest. Dermatol. 134, 2026-2035. doi: 10.1038/jid.2014.86

Penuela, S., Simek, J., and Thompson, R. J. (2014b). Regulation of pannexin channels by post-translational modifications. FEBS Lett. 588, 1411-1415. doi: 10. 1016/j.febslet.2014.01.028

Postlethwait, J. H. (2007). The zebrafish genome in context: ohnologs gone missing. J. Exp. Zool. B Mol. Dev. Evol. 308, 563-577. doi: 10.1002/jez.b.21137

Pottek, M., Hoppenstedt, W., Janssen-Bienhold, U., Schultz, K., Perlman, I., and Weiler, R. (2003). Contribution of connexin26 to electrical feedback inhibition in the turtle retina. J. Comp. Neurol. 466, 468-477. doi: 10.1002/cne. 10897

Prochnow, N., Abdulazim, A., Kurtenbach, S., Wildforster, V., Dvoriantchikova, G., Hanske, J., et al. (2012). Pannexin 1 stabilizes synaptic plasticity and is needed for learning. PLoS One 7:e51767. doi: 10.1371/journal.pone.0051767

Prochnow, N., Hoffmann, S., Vroman, R., Klooster, J., Bunse, S., Kamermans, M., et al. (2009). Pannexin1 in the outer retina of the zebrafish, Danio rerio. Neuroscience 162, 1039-1054. doi: 10.1016/j.neuroscience.2009.04.064 
Puthussery, T., Yee, P., Vingrys, A. J., and Fletcher, E. L. (2006). Evidence for the involvement of purinergic P2X receptors in outer retinal processing. Eur. J. Neurosci. 24, 7-19. doi: 10.1111/j.1460-9568.2006.04895.x

Qiu, F., and Dahl, G. (2009). A permeant regulating its permeation pore: inhibition of pannexin 1 channels by ATP. Am. J. Physiol. Cell Physiol. 296, C250-C255. doi: 10.1152/ajpcell.00433.2008

Qiu, F., Wang, J., Spray, D. C., Scemes, E., and Dahl, G. (2011). Two non-vesicular ATP release pathways in the mouse erythrocyte membrane. FEBS Lett. 585, 3430-3435. doi: 10.1016/j.febslet.2011.09.033

Ravi, V., and Venkatesh, B. (2008). Rapidly evolving fish genomes and teleost diversity. Curr. Opin. Genet. Dev. 18, 544-550. doi: 10.1016/j.gde.2008. 11.001

Ray, A., Zoidl, G., Wahle, P., and Dermietzel, R. (2006). Pannexin expression in the cerebellum. Cerebellum 5, 189-192. doi: 10.1080/14734220500530082

Ray, A., Zoidl, G., Weickert, S., Wahle, P., and Dermietzel, R. (2005). Site-specific and developmental expression of pannexin 1 in the mouse nervous system. Eur. J. Neurosci. 21, 3277-3290. doi: 10.1111/j.1460-9568.2005.04139.x

Reigada, D., Lu, W., Zhang, M., and Mitchell, C. H. (2008). Elevated pressure triggers a physiological release of ATP from the retina: possible role for pannexin hemichannels. Neuroscience 157, 396-404. doi: 10.1016/j.neuroscience.2008. 08.036

Resta, V., Novelli, E., Vozzi, G., Scarpa, C., Caleo, M., Ahluwalia, A., et al. (2007) Acute retinal ganglion cell injury caused by intraocular pressure spikes is mediated by endogenous extracellular ATP. Eur. J. Neurosci. 25, 2741-2754. doi: 10.1111/j.1460-9568.2007.05528.x

Retamal, M. A. (2014). Connexin and Pannexin hemichannels are regulated by redox potential. Front. Physiol. 5:80. doi: 10.3389/fphys.2014.00080

Retamal, M. A., Schalper, K. A., Shoji, K. F., Bennett, M. V., and Saez, J. C. (2007). Opening of connexin 43 hemichannels is increased by lowering intracellular redox potential. Proc. Natl. Acad. Sci. U S A 104, 8322-8327. doi: 10.1073/pnas. 0702456104

Romanov, R. A., Rogachevskaja, O. A., Bystrova, M. F., Jiang, P., Margolskee, R. F., and Kolesnikov, S. S. (2007). Afferent neurotransmission mediated by hemichannels in mammalian taste cells. EMBO J. 26, 657-667. doi: 10.1038/sj. emboj.7601526

Sabirov, R. Z., Dutta, A. K., and Okada, Y. (2001). Volume-dependent ATPconductive large-conductance anion channel as a pathway for swelling-induced ATP release. J. Gen. Physiol. 118, 251-266. doi: 10.1085/jgp.118.3.251

Saez, J. C., and Leybaert, L. (2014). Hunting for connexin hemichannels. FEBS Lett. 588, 1205-1211. doi: 10.1016/j.febslet.2014.03.004

Santiago, M. F., Veliskova, J., Patel, N. K., Lutz, S. E., Caille, D., Charollais, A., et al. (2011). Targeting pannexin1 improves seizure outcome. PLoS One 6:e25178. doi: 10.1371/journal.pone.0025178

Schalper, K. A., Orellana, J. A., Berthoud, V. M., and Saez, J. C. (2009). Dysfunctions of the diffusional membrane pathways mediated by hemichannels in inherited and acquired human diseases. Curr. Vasc. Pharmacol. 7, 486-505. doi: 10. 2174/157016109789043937

Schenk, U., Westendorf, A. M., Radaelli, E., Casati, A., Ferro, M., Fumagalli, M., et al. (2008). Purinergic control of T cell activation by ATP released through pannexin-1 hemichannels. Sci. Signal. 1:ra6. doi: 10.3410/f.1123131.580258

Seminario-Vidal, L., Kreda, S., Jones, L., O’Neal, W., Trejo, J., Boucher, R. C., et al. (2009). Thrombin promotes release of ATP from lung epithelial cells through coordinated activation of rho- and Ca2+-dependent signaling pathways. J. Biol. Chem. 284, 20638-20648. doi: 10.1074/jbc.M109.004762

Seminario-Vidal, L., Okada, S. F., Sesma, J. I., Kreda, S. M., van Heusden, C. A., $\mathrm{Zhu}$, Y., et al. (2011). Rho signaling regulates pannexin 1-mediated ATP release from airway epithelia. J. Biol. Chem. 286, 26277-26286. doi: 10.1074/jbc.M111. 260562

Séror, C., Melki, M. T., Subra, F., Raza, S. Q., Bras, M., Saidi, H., et al. (2011). Extracellular ATP acts on P2Y2 purinergic receptors to facilitate HIV-1 infection. J. Exp. Med. 208, 1823-1834. doi: 10.1084/jem.20101805

Shahidullah, M., Mandal, A., and Delamere, N. A. (2012). TRPV4 in porcine lens epithelium regulates hemichannel-mediated ATP release and Na-K-ATPase activity. Am. J. Physiol. Cell Physiol. 302, C1751-C1761. doi: 10.1152/ajpcell. 00010.2012

Shearer, T. W., and Crosson, C. E. (2002). Adenosine Al receptor modulation of MMP-2 secretion by trabecular meshwork cells. Invest. Ophthalmol. Vis. Sci. 43, 3016-3020.
Silverman, W. R., De Rivero Vaccari, J. P., Locovei, S., Qiu, F., Carlsson, S. K., Scemes, E., et al. (2009). The pannexin 1 channel activates the inflammasome in neurons and astrocytes. J. Biol. Chem. 284, 18143-18151. doi: 10.1074/jbc. M109.004804

Silverman, W., Locovei, S., and Dahl, G. (2008). Probenecid, a gout remedy, inhibits pannexin 1 channels. Am. J. Physiol. Cell Physiol. 295, C761-C767. doi: 10. 1152/ajpcell.00227.2008

Skapinker, R., and Rothberg, A. D. (1987). Postnatal regression of the tunica vasculosa lentis. J. Perinatol. 7, 279-281.

Sosinsky, G. E., Boassa, D., Dermietzel, R., Duffy, H. S., Laird, D. W., MacVicar, B., et al. (2011). Pannexin channels are not gap junction hemichannels. Channels (Austin) 5, 193-197. doi: 10.4161/chan.5.3.15765

Sridharan, M., Adderley, S. P., Bowles, E. A., Egan, T. M., Stephenson, A. H., Ellsworth, M. L., et al. (2010). Pannexin 1 is the conduit for low oxygen tensioninduced ATP release from human erythrocytes. Am. J. Physiol. Heart Circ. Physiol. 299, H1146-H1152. doi: 10.1152/ajpheart.00301.2010

Suadicani, S. O., Iglesias, R., Wang, J., Dahl, G., Spray, D. C., and Scemes, E. (2012). ATP signaling is deficient in cultured Pannexin1-null mouse astrocytes. Glia 60, 1106-1116. doi: 10.1002/glia.22338

Sun, Z., Risner, M. L., van Asselt, J. B., Zhang, D. Q., Kamermans, M., and McMahon, D. G. (2012). Physiological and molecular characterization of connexin hemichannels in zebrafish retinal horizontal cells. J. Neurophysiol. 107, 2624-2632. doi: 10.1152/jn.01126.2011

Tang, W., Ahmad, S., Shestopalov, V. I., and Lin, X. (2008). Pannexins are new molecular candidates for assembling gap junctions in the cochlea. Neuroreport 19, 1253-1257. doi: 10.1097/WNR.0b013e32830891f5

Thompson, R. J., Jackson, M. F., Olah, M. E., Rungta, R. L., Hines, D. J., Beazely, M. A., et al. (2008). Activation of pannexin-1 hemichannels augments aberrant bursting in the hippocampus. Science 322, 1555-1559. doi: 10.1126/science. 1165209

Toris, C. B., Gabelt, B. T., and Kaufman, P. L. (2008). Update on the mechanism of action of topical prostaglandins for intraocular pressure reduction. Surv. Ophthalmol. 53(Suppl. 1), S107-S120. doi: 10.1016/j.survophthal.2008. 08.010

Ueda, T., Shikano, M., Kamiya, T., Joh, T., and Ugawa, S. (2011). The TRPV4 channel is a novel regulator of intracellular $\mathrm{Ca} 2+$ in human esophageal epithelial cells. Am. J. Physiol. Gastrointest. Liver Physiol. 301, G138-G147. doi: 10. 1152/ajpgi.00511.2010

Vanden Abeele, F., Bidaux, G., Gordienko, D., Beck, B., Panchin, Y. V., Baranova, A. V., et al. (2006). Functional implications of calcium permeability of the channel formed by pannexin 1. J. Cell Biol. 174, 535-546. doi: 10.1083/jcb. 200601115

Vogt, A., Hormuzdi, S. G., and Monyer, H. (2005). Pannexin1 and Pannexin2 expression in the developing and mature rat brain. Brain Res. Mol. Brain Res. 141, 113-120. doi: 10.1016/j.molbrainres.2005.08.002

Volgyi, B., Kovacs-Oller, T., Atlasz, T., Wilhelm, M., and Gabriel, R. (2013). Gap junctional coupling in the vertebrate retina: variations on one theme? Prog. Retin. Eye Res. 34, 1-18. doi: 10.1016/j.preteyeres.2012.12.002

Vroman, R., Klaassen, L. J., Howlett, M. H., Cenedese, V., Klooster, J., Sjoerdsma, T., et al. (2014). Extracellular ATP hydrolysis inhibits synaptic transmission by increasing ph buffering in the synaptic cleft. PLoS Biol. 12:e1001864. doi: 10. 1371/journal.pbio.1001864

Vroman, R., Klaassen, L. J., and Kamermans, M. (2013). Ephaptic communication in the vertebrate retina. Front. Hum. Neurosci. 7:612. doi: 10.3389/fnhum.2013. 00612

Wang, J., Jackson, D. G., and Dahl, G. (2013). The food dye FD\&C Blue No. 1 is a selective inhibitor of the ATP release channel Panx1. J. Gen. Physiol. 141, 649656. doi: 10.1085/jgp.201310966

Wang, X. H., Streeter, M., Liu, Y. P., and Zhao, H. B. (2009). Identification and characterization of pannexin expression in the mammalian cochlea. J. Comp. Neurol. 512, 336-346. doi: 10.1002/cne.21898

Weilinger, N. L., Tang, P. L., and Thompson, R. J. (2012). Anoxia-induced NMDA receptor activation opens pannexin channels via Src family kinases. J. Neurosci. 32, 12579-12588. doi: 10.1523/JNEUROSCI.1267-12.2012

Woehrle, T., Yip, L., Elkhal, A., Sumi, Y., Chen, Y., Yao, Y., et al. (2010). Pannexin1 hemichannel-mediated ATP release together with $\mathrm{P} 2 \mathrm{X} 1$ and $\mathrm{P} 2 \mathrm{X} 4$ receptors regulate T-cell activation at the immune synapse. Blood 116, 3475-3484. doi: 10 . 1182/blood-2010-04-277707 
Wong, W. T., Wang, M., and Li, W. (2011). Regulation of microglia by ionotropic glutamatergic and GABAergic neurotransmission. Neuron Glia Biol. 7, 41-46. doi: 10.1017/S1740925x11000123

Xia, J., Lim, J. C., Lu, W., Beckel, J. M., Macarak, E. J., Laties, A. M., et al. (2012) Neurons respond directly to mechanical deformation with pannexin-mediated ATP release and autostimulation of P2X7 receptors. J. Physiol. 590, 2285-2304. doi: 10.1113/jphysiol.2012.227983

Xiang, Z., Chen, M., Ping, J., Dunn, P., Lv, J., Jiao, B., et al. (2006). Microglial morphology and its transformation after challenge by extracellular ATP in vitro. J. Neurosci. Res. 83, 91-101. doi: 10.1002/jnr.20709

Xin, D., and Bloomfield, S. A. (1999). Dark- and light-induced changes in coupling between horizontal cells in mammalian retina. J. Comp. Neurol. 405, 75-87. doi: 10.1002/(sici)1096-9861(19990301)405:1<75::aid-cne6>3.0. co;2-d

Yang, L., Mali, P., Kim-Kiselak, C., and Church, G. (2014). CRISPR-Cas-mediated targeted genome editing in human cells. Methods Mol. Biol. 1114, 245-267. doi: 10.1007/978-1-62703-761-7_16

Zappalà, A., Cicero, D., Serapide, M. F., Paz, C., Catania, M. V., Falchi, M., et al. (2006). Expression of pannexin 1 in the CNS of adult mouse: cellular localization and effect of 4-aminopyridine-induced seizures. Neuroscience 141, 167-178. doi: 10.1016/j.neuroscience.2006.03.053

Zappalà, A., Li Volti, G., Serapide, M. F., Pellitteri, R., Falchi, M., La Delia, F. et al. (2007). Expression of pannexin2 protein in healthy and ischemized brain of adult rats. Neuroscience 148, 653-667. doi: 10.1016/j.neuroscience.2007. 06.028

Zhang, H., Chen, Y., and Zhang, C. (2012). Patterns of heterogeneous expression of pannexin 1 and pannexin 2 transcripts in the olfactory epithelium and olfactory bulb. J. Mol. Histol. 43, 651-660. doi: 10.1007/s10735-0129443-x
Zhang, X., Li, A., Ge, J., Reigada, D., Laties, A. M., and Mitchell, C. H. (2007). Acute increase of intraocular pressure releases ATP into the anterior chamber. Exp. Eye Res. 85, 637-643. doi: 10.1016/j.exer.2007.07.016

Zhang, J., Peng, S., Lin, M., and Du, C. (2005). [Clinical study of twenty-fourhour pattern of intraocular pressure in normal person and patient with primary open-angle glaucoma]. Yan Ke Xue Bao 21, 127-130.

Zoidl, G., Kremer, M., Zoidl, C., Bunse, S., and Dermietzel, R. (2008). Molecular diversity of connexin and pannexin genes in the retina of the zebrafish Danio rerio. Cell Commun. Adhes. 15, 169-183. doi: 10.1080/15419060802014081

Zoidl, G., Petrasch-Parwez, E., Ray, A., Meier, C., Bunse, S., Habbes, H. W., et al. (2007). Localization of the pannexinl protein at postsynaptic sites in the cerebral cortex and hippocampus. Neuroscience 146, 9-16. doi: 10.1016/j. neuroscience.2007.01.061

Conflict of Interest Statement: The authors declare that the research was conducted in the absence of any commercial or financial relationships that could be construed as a potential conflict of interest.

Received: 07 May 2014; accepted: 14 August 2014; published online: 15 September 2014.

Citation: Kurtenbach S, Kurtenbach S and Zoidl G (2014) Emerging functions of pannexin 1 in the eye. Front. Cell. Neurosci. 8:263. doi: 10.3389/fncel.2014.00263 This article was submitted to the journal Frontiers in Cellular Neuroscience. Copyright (C) 2014 Kurtenbach, Kurtenbach and Zoidl. This is an open-access article distributed under the terms of the Creative Commons Attribution License (CC BY). The use, distribution or reproduction in other forums is permitted, provided the original author(s) or licensor are credited and that the original publication in this journal is cited, in accordance with accepted academic practice. No use, distribution or reproduction is permitted which does not comply with these terms. 